\title{
Purification and characterization of a proline iminopeptidase from Propionibacterium shermanii 13673
}

\author{
G Panon \\ Laboratoire de Recherche de Technologie Laitière, INRA, \\ 65, rue de Saint-Brieuc, 35042 Rennes Cedex, France
}

(Received 18 July 1990; accepted 17 September 1990)

\begin{abstract}
Summary - A proline iminopeptidase activity was found in $P$ shermanii 13673. The enzyme activity was present in the intracellular fraction. The peptidase was purified approximately 80 times by ionexchange chromatography on Fractogel TSK DEAE 650 and gel filtration on Sephacryl S-100 HR. The purified enzyme appeared as a single band after sodium dodecyl sulfate-polyacrylamide gel electrophoresis. It had a molecular weight of 61000 . Optima for activity of the purified enzyme were $40^{\circ} \mathrm{C}$ and $\mathrm{pH} 8.0$. The enzymatic activity was inhibited by phenylmethylsulfonylfluoride $(1 \mathrm{mM})$. Divalent ions $\mathrm{Zn}, \mathrm{Co}, \mathrm{Cu}$ and $\mathrm{Fe}$ also had an inhibitory effect. The peptidase hydrolyzed specifically Pro $p$-NA amino acid, dipeptides Pro-Met, Pro-Phe, Pro-Le, Pro-lleu, Pro-Gly and $\beta$-casomorphin des-Tyr fragment 7.
\end{abstract}

Propionibacterium shermanii / enzyme / peptidase / proline / purification

Résumé - Purification et caractérisation d'une proline iminopeptidase à partir de la souche Propionibacterium shermanii 13673. Une activité de proline iminopeptidase a été mise en évidence dans la souche $\mathrm{P}$ shermanii 13673. L'activité enzymatique est présente dans la fraction intracellulaire. L'enzyme a été purifiée environ 80 fois par chromatographie d'échange d'ions sur fractogel TSK DEAE 650 et gel filtration sur Sephacryl S-100 HR. L'enzyme purifiée présente une seule bande après électrophorèse en gel de polyacrylamide et en présence de SDS. Elle a un poids moléculaire de 61000 . La température est de $40^{\circ} \mathrm{C}$ et le $\mathrm{pH}$ optimal de 8,0 . L'activité enzymatique est inhibée par le phénylméthylfulfonyl fluoride (1 mM). Les ions divalents $\mathrm{Zn}, \mathrm{Co}, \mathrm{Cu}$ et $\mathrm{Fe}$ ont aussi un effet inhibiteur. La peptidase hydrolyse spécifiquement la Pro p-NA, les dipeptides Pro-Met, ProPhe, Pro-Leu, Pro-lle, Pro-Gly et le fragment 7 des-Tyr de la $\beta$-casomorphine.

Propionibacterium shermanii / enzyme / peptidase / proline / purification 


\section{INTRODUCTION}

Proteolysis is probably the most important biochemical event during the ripening of most cheese varieties with a major impact on flavor and texture. The mechanisms of flavor compound formation in hard cheeses involve successive steps and several agents: rennet, indigenous milk proteinases, starter proteinases and peptidases, enzymes from secondary starters and from non starter microorganisms. Thermophilic acid bacteria such as Streptococcus thermophilus, Lactobacillus helveticus and Lactobacillus lactis are normally used as starter bacteria in Swiss cheese industries, whereas propionic acid bacteria are added as secondary starters. The initial lactic fermentation by the starters is followed by fermention of lactate and residual sugars due to presence of propionic acid bacteria. This is a vital stage in Swiss cheese ripening.

Enzyme activities and proteolysis during cheese maturation have been reviewed by Fox (1989) and by Kamaly and Marth (1989). Purification of peptidases from starter bacteria has been reported by Rabier and Desmazeaud (1973), Desmazeaud and Juge (1976), Eggimann and Bachmann (1980), Desmazeaud (1982), El Soda and Demazeaud (1982), Ezzat $e t$ al (1982), Hickey et al (1983), Casey and Meyer (1985), Meyer and Jordi (1987) and Khalid and Marth (1990).

Proteolytic system from secondary starters has also been studied by Langsrud (1974). Four or 5 peptidases in a strain of Propionibacterium shermanii have been detected, one of which was a proline iminopeptidase. Langsrud et al (1977) found that propionibacteria released large amounts of proline when grown in media containing peptides. Langsrud et al (1978b) established that propionibacteria also produced intracellular peptidases which were released by autolysis in hard cheeses. Sahlstrom et al (1989) found peptidase activities in cell wall, membrane and intracellular fractions of $P$ shermanii. Perez Chaia et al (1990), studying the activity of peptidases belonging to propionibacteria, found a greater affinity for proline $p$-nitroanilide than for leucine $p$ nitroanilide.

In this work we have purified (with good reasons for presuming homogeneity) and characterized a proline iminopeptidase from $P$ shermanii 13673. This is the first report describing the purification and characterization of a proline iminopeptidase from a cell extract of propionic acid bacteria.

\section{MATERIAL AND METHODS}

\section{Chemicals}

Lysozyme, mutanolysin, DNase, RNase, all peptide derivatives were obtained from Sigma Chemical Co, St Louis, MO, USA. Fractogel TSK DEAE 650 was purchased from E Merck, Darmstadt, Germany. Sephacryl S100 HR and molecular weight markers were obtained from Pharmacia-LKB, Saint-Quentin en Yvelines, France.

\section{Bacterial strains}

Five strains from our collection were studied. The strain of $P$ globosum 408 was supplied by a starter bacteria producer, Standa-Industrie, Caen, France. The strain of $P$ freudenreichii CNRZ 435 was supplied from the culture collection of the Centre de Recherches (CNRZ), Jouyen-Josas, France. $P$ shermanii 13673 and the 2 strains of $P$ acidi propionici 4875 and P01 were obtained from one private Emmental industry.

All strains were identified according to Bergey's Manual of Determinative Bacteriology (More and Holdeman, 1974) and the method of Britz and Steyn (1980) and the method of Britz 
and Steyn (1980) and also by control of propionic acid production (HPLC method).

\section{Growth conditions}

The strains were maintained on yeast extract lactate (YEL) medium (Hettinga et al, 1968): sodium lactate $1 \%$ (Merck), $\mathrm{K}_{2} \mathrm{HPO}_{4} 0.025 \%$ (Prolabo), $\mathrm{MgSO}_{4} 0.005 \%$ (Prolabo), biotrypticase $1 \%$ (BioMérieux), yeast extract $1 \%$ (Biokar); $\mathrm{pH}$ was ajusted to 7.0 and medium autoclaved for $15 \mathrm{~min}$ at $121^{\circ} \mathrm{C}$. Strains were transferred 3 times in 10-ml tubes. Cultures of 2 I were grown in YEL medium with an inoculum of $1 \%$. Growth was maintained at $30^{\circ} \mathrm{C}$ for $48 \mathrm{~h}$.

\section{Preparation of cell extracts}

At the end of the exponential growth period the cells were harvested and centrifuged at 10000 $g$ for $15 \mathrm{~min}$. The supernatants were stored at $-20^{\circ} \mathrm{C}$. The cell pellets were washed twice in $200 \mathrm{ml}$ of $50 \mathrm{mM} \beta$ glycerophosphate, $\mathrm{pH} 7.0$.

Washed cells were then treated by protoplast buffer: $100 \mathrm{ml}$ of $50 \mathrm{mM} / \mathrm{l}$ Tris buffer, $\mathrm{pH} 7.0 \mathrm{con}$ taining $0.5 \mathrm{M}$ saccharose, lysozyme at $5 \mathrm{mg} / \mathrm{ml}$ and mutanolysin at $5 \mu \mathrm{g} / \mathrm{ml}$ (Kondo and McKay, 1982). After incubation at $37^{\circ} \mathrm{C}$ for $2 \mathrm{~h}$ the protoplasts were recovered by centrifugation at 5500 $g$ for $20 \mathrm{~min}$. Protoplast supernatants were stored at $-20^{\circ} \mathrm{C}$ after filtration. Cells were disrupted by osmotic shock in alkaline buffer $(\mathrm{pH}$ 12). $\mathrm{pH}$ was immediately adjusted to 7.0 with 2 $M$ Tris buffer.

After DNase and RNase treatment $0.1 \mathrm{mg} /$ $\mathrm{ml}$ ) the crude extract was then centrifuged at $24000 \mathrm{~g}$ for $30 \mathrm{~min}$ at $4^{\circ} \mathrm{C}$ in order to eliminate intact cells and cell debris. The cell-free extracts designated as the cytoplasmic or intracellular fractions were stored at $-20^{\circ} \mathrm{C}$, before aminopeptidase activity investigations. The intracellular fraction of $P$ shermanii 13673 was used as starting material for the purification of the peptidase.

\section{Substrate specificity}

Intracellular fractions were tested with L-leucine $p$-nitroanilide (Leu $p$-NA), L-lysine $p$-nitroanilide
(Lys $p$-NA), L-Proline p-nitroanilide (Pro p-NA) and L-glycine $p$-nitroanilide (Gly $p$-NA) substrates. Protein extracts from purification were routinely tested with Pro $p$-NA substrate.

Aminopeptidase activity was assayed by incubation of intracellular preparation with 0.75 $\mathrm{mM}$ p-nitroanilide amino acids in $20 \mathrm{mM}$ Tris$\mathrm{HCl}$ buffer $\mathrm{pH} 7.0$. Incubation was carried out at $37^{\circ} \mathrm{C}$ for $1 \mathrm{~h}$. The reaction was stopped by the addition of $30 \%$ acetic acid. The supernatant was separated by centrifugation at $10000 \mathrm{~g}$ for $5 \mathrm{~min}$. The release of $p$-nitroanilide was followed by measuring absorbance at $410 \mathrm{~nm}\left(\mathrm{~A}_{410}\right)$ in an Uvikon Kontron 860 spectrophotometer. One unit of aminopeptidase activity was defined as the amount of enzyme which produced a variation of 0.01 unit of $A_{410}$ per min at $37^{\circ} \mathrm{C}$. The purified enzyme was also tested against several di- and tripeptides. Purified enzyme was incubated with $0.4 \mathrm{mM}$ substrate in phosphate buffer $\mathrm{pH} 7.0$. After incubation at $37^{\circ} \mathrm{C}$ for $1 \mathrm{~h}$, free $\alpha$ amino groups were determined with 1 vol of ninhydrin $(20 \mathrm{~g}$ of ninhydrin, $750 \mathrm{ml}$ of methylcellosolve (ethylene glycol monomethyl ether), 250 $\mathrm{ml}$ of $4 \mathrm{M}$ acetate buffer ( $\mathrm{pH} 5.51), 7 \mathrm{ml}$ of titanium chloride). The preparation was boiled at $100^{\circ} \mathrm{C}$ for $5 \mathrm{~min}$ and $3 \mathrm{vol}$ of $50 \%$ ethanol were added. Hydrolysis was followed at $A_{440}$ for proline, and $A_{570}$ for the other amino acids.

Substrate specificity of the peptidase was also tested by HPLC against bovine $\beta$ casomorphin fragments: fragment $1-3$, morphoceptin ( $\beta$-casomorphin 1-4 amide), fragment 15 and des-Tyr-fragment 7. The purified enzyme was incubated with $0.4 \mathrm{mM}$ substrate in $20 \mathrm{mM}$ Tris buffer $\mathrm{pH} 7.0$ for $3 \mathrm{~h}$ at $40^{\circ} \mathrm{C}$. The reaction mixtures and substrates were injected onto a Vydac column C $185 \mu$. Peptides were eluted by a gradient water/acetonitrile ( $1 \mathrm{vol} / 4 \mathrm{vol})$.

\section{Purification}

\section{First ion exchange chromatography}

The first ion exchange chromatography was performed with a Fractogel TSK DEAE 650 column. The column $(2.6 \mathrm{~cm} \times 40)$ was equilibrated with $20 \mathrm{mM}$ Tris- $\mathrm{HCl}$ buffer $\mathrm{pH}$ 7.0. One hundred $\mathrm{mI}$ of intracellular fraction of $P$ shermanii 13673 were dialyzed and centrifuged. This fraction (3 $000 \mathrm{mg}$ ) was applied to the column. After 
washing the column with the equilibration buffer, the enzyme was eluted with a linear gradient of 0 to $0.6 \mathrm{M} \mathrm{NaCl}$ in the same buffer at a flow rate of $90 \mathrm{ml} / \mathrm{h}$. Fractions of $11.2 \mathrm{ml}$ each were collected and tested for protein concentration by measuring absorbance at $280 \mathrm{~nm}\left(A_{280}\right)$. Peptidase activity was tested with Pro p-NA substrate. Active fractions (Nos 36-45) were pooled and stored at $-20^{\circ} \mathrm{C}$ in the presence of stabilizers according to the method of Neviani et al (1989).

\section{Second ion exchange chromatography}

The enzyme active fractions of the first performed chromatography were dialyzed against $20 \mathrm{mM}$ Tris $-\mathrm{HCl} \mathrm{pH} 7.0$ at $4{ }^{\circ} \mathrm{C}$ and applied to the same Fractogel TSK DEAE column previously equilibrated with $20 \mathrm{mM}$ Tris-HCl buffer $\mathrm{pH}$ 7.0. The column was washed with $20 \mathrm{mM}$ Tris- $\mathrm{HCl}$; the enzyme was eluted with a linear gradient of $\mathrm{NaCl} 0-0.5 \mathrm{M}$ in $20 \mathrm{mM}$ Tris $-\mathrm{HCl} \mathrm{pH}$ 7.0 at a flow rate of $90 \mathrm{ml} / \mathrm{h}$, and $11.2-\mathrm{ml}$ fractions collected. Active fractions (Nos 38-46) against Pro p-NA substrate were pooled and dialyzed against $20 \mathrm{mM}$ Tris- $\mathrm{HCl}$ buffer $\mathrm{pH} 7.0$ at $4^{\circ} \mathrm{C}$. They were concentrated by PEG 3000 before gel filtration.

\section{Gel filtration}

The concentrated enzyme $(9 \mathrm{ml})$ was further purified on a Sephacryl S-100 HR column (2.6 $\mathrm{cm} \times 100$ ) previously equilibrated with $20 \mathrm{mM}$ Tris- $\mathrm{HCl}$ buffer $\mathrm{pH} 7.0$ containing $1 \mathrm{M} \mathrm{NaCl}$. A flow rate of $120 \mathrm{mi} / \mathrm{h}$ was applied and $8-\mathrm{ml}$ fractions were collected from the column. The enzyme was eluted from the column as a single peak. Active fractions (Nos 11-15) against Pro $p$-NA substrate were pooled and dialysed against $20 \mathrm{mM}$ Tris- $\mathrm{HCl}$ buffer $\mathrm{pH} 7.0$ at $4{ }^{\circ} \mathrm{C}$. Characterization of the enzyme was performed with this preparation.

\section{Polyacrylamide gel electrophoresis}

Each purification step was examined by sodium dodecyl sulfate-polyacrylamide gel electrophoresis (SDS-PAGE) with the Laemmli buffer system (Laemmli, 1970). A $3 \%$ stacking gel and a
$10 \%$ running gel were prepared. The protein samples were mixed $1 / 1$ with sample buffer (10 mM Tris- $\mathrm{HCl} \mathrm{pH} 6.8,20 \%$ glycerol, $2 \%$ SDS, 5\% 2-mercapto-ethanol and $0.001 \%$ bromophenol blue), boiled for 5 min, and applied to the gel. After a $6-\mathrm{h}$ run at $150 \mathrm{~V}$, proteins were stained with Coomassie blue R. For destaining, the gels were put into a solution of $10 \%(\mathrm{v} / \mathrm{v})$ acetic acid, $10 \%(\mathrm{v} / \mathrm{v})$ methanol in water.

\section{Determination of molecular weight}

Molecular size of the active enzyme was estimated by gel filtration on Sephacryl S-100 HR in column $2.6 \times 100$. The column was first calibrated with bovine serum albumin ( $67 \mathrm{kDa})$, ovalbumin (43 kDa) and lysozyme (14.3 kDa). Molecular size was also estimated by SDS-PAGE. The low molecular weight standards used were obtained from Pharmacia (Uppsala, Sweden): phosphorylase b (94 kDa), bovine serum albumin (67 kDa), ovalbumin (43 kDa), bovine carbonic anhydrase (30 kDa), soybean trypsin inhibitor (20.1 kDa) and $\alpha$-lactalbumin (14.4 kDa). The molecular weight of the aminopeptidase was determined by a reference to a standard graph relating log of molecular weight of each standard to its relative mobility.

\section{Effect of reducing agents, metal chelators and inhibitors on enzyme activity}

A diverse range of compounds known to inhibit various proteases were tested for their effects on the peptidase activity of $P$ shermanii 13673 . Reducing agents and thiol, metallo, serine protease inhibitors were tested. The enzyme was preincubated in $20 \mathrm{mM}$ Tris $-\mathrm{HCl} \mathrm{pH} 7.0$ for 15 min at $20^{\circ} \mathrm{C}$ with the following agents: dithiothreitol, L-cysteine, 2-merceptoethanol, Nethylmaleimide, iodoacetic acid, iodoacetamide, p-chloromercuric benzoic acid, ethylenediaminetetraacetic acid (EDTA), 1-10 phenanthroline, bestatin, phosphoramidon, phenylmethylsulfonyl fluoride, pepstatin $\mathrm{A}$ and sodium citrate. Two final concentrations were used: $0.1 \mathrm{mM}$ and $1 \mathrm{mM}$ ( 1 and $10 \mathrm{mM}$ for EDTA). Pro p-NA was added as substrate and enzyme activity was measured after incubation at $37^{\circ} \mathrm{C}$ for $60 \mathrm{~min}$ at $A_{410}$. 


\section{Effect of metal ions on enzyme activity}

Effects of divalent ions were tested on enzyme activity. The purified and dialyzed enzyme was incubated in the presence or the absence of $\mathrm{Ca}$ chloride, Co acetate, Cu sulfate, $\mathrm{Zn}, \mathrm{Mn}$ sulfate and $\mathrm{Mg}$ chloride at a final concentration of 0.1 $\mathrm{mM}$. Reaction mixtures were preincubated for $15 \mathrm{~min}$ at $20^{\circ} \mathrm{C}$ in $20 \mathrm{mM}$ Tris- $\mathrm{HCl}$ buffer $(\mathrm{pH}$ 7.0) prior to the addition of Pro p-NA. The enzyme activity was determined at $37^{\circ} \mathrm{C}$ for $60 \mathrm{~min}$ at $\mathrm{A}_{410}$.

\section{Protein estimation}

The BioRad method (BioRad Laboratories, Watford, England) was used with bovine serum albumin as standard (Bradford, 1976). Elution profiles of the proteins separated after Fractogel TSK DEAE 650 and Sephacryl S-100 HR were determined at $A_{280}$.

\section{Effect of pH on enzyme activity}

The effect of pH from 4.0 to 10.0 on peptidase activity was determined by using $20 \mathrm{mM}$ glycine- $\mathrm{NaCl}$ or Tris- $\mathrm{HCl}$ buffer adjusted to the appropriate $\mathrm{pH}$ values. Enzyme activity was measured at $37^{\circ} \mathrm{C}$ for $60 \mathrm{~min}$ with Pro $p-N A$ as substrate at $A_{410}$.

\section{Effect of temperature on enzyme activity}

The effect of temperature was measured in the range of $5-70^{\circ} \mathrm{C}$. The $20 \mathrm{mM}$ Tris- $\mathrm{HCl}$ buffer (pH 7.5) was equilibrated for $15 \mathrm{~min}$ at the test temperature. Fifty $\mu \mathrm{l}$ of purified enzyme and 50 $\mu$ of Pro $p$-NA as substrate were added and the enzyme activity was measured after $60 \mathrm{~min}$ of incubation at the test temperatures at $A_{410}$.

\section{Amino acid analysis}

The purified enzyme was hydrolyzed with $6 \mathrm{~N}$ $\mathrm{HCl}$ under vacuum at $110^{\circ} \mathrm{C}$ for $24 \mathrm{~h}$. Amino ac- ids were quantitatively assayed with an amino acid analyzer Pharmacia-LKB alpha plus.

\section{RESULTS}

\section{Peptidase purification}

Enzymatic treatment of propionibacterial cells was preferred to physical treatment because it does not generate high shear stresses and minimises product damage (Andrews and Asenjo, 1987). Peptidase activity was observed in the cell wall fraction (data not shown), probably due to partial cell lysis during protoplast formation.

The major peptidase activities with leucine, lysine, proline and glycine $p$ nitroanilide substrates were present in the soluble intracellular fraction of 5 strains of propionibacteria (table I). For all extracts

Table I. Hydrolysis of $p$-nitroanilide ( $p$-NA) substituted amino acids (leucine, lysine, proline, glycine) by intracellular fraction of $P$ globosum 408 , $P$ freudenreichii CNRZ 435, $P$ shermanii 13673 , $P$ acidi propionici $4875, P$ acidi propionici PO1. Results are expressed in units of activity per min at $37^{\circ} \mathrm{C}$.

Hydrolyse des acides aminés (leucine, lysine, proline, glycine) substitués ( $\mathrm{p}-\mathrm{NA}$ ) par les fractions intracellulaires de $\mathrm{P}$ globosum 408 , $\mathrm{P}$ freudenreichii CNRZ 435, P shermanii 13673, $\mathrm{P}$ acidi propionici $4875, \mathrm{P}$ acidi propionici $P 01$. Les résultats sont exprimés en unités d'activité par min à $37^{\circ} \mathrm{C}$.

\section{Substrate \\ Leu Lys Pro Gly \\ $\mathrm{p}-N A \mathrm{p}-N A \mathrm{p}-N A \mathrm{p}-N A$}

\begin{tabular}{lrrrr}
\hline P globosum 408 & 75 & 0 & 180 & 75 \\
$P$ freudenreichii Z 435 & 150 & 0 & 750 & 0 \\
$P$ shermanii 13673 & 180 & 150 & 2660 & 0 \\
$P$ acidi propionici 4875 & 100 & 0 & 500 & 0 \\
$P$ acidi propionici PO1 & 200 & 0 & 600 & 0 \\
\hline
\end{tabular}


we observed a stronger activity with Pro $p$ NA than with Leu $p$-NA substrate.

After this result we decided to study $P$ shermanii 13673 more particularly and to purify the specific aminopeptidase. In the first ion exchange chromatography performed on Fractogel TSK DEAE 650 the proline activity was eluted from the column at $0.4 \mathrm{M} \mathrm{NaCl}$ (fig 1). During the second ion exchange chromatography on the same Fractogel TSK DEAE 650, the enzyme was eluted at $0.4 \mathrm{M} \mathrm{NaCl}$.

After gel filtration on Sephacryl S-100 HR the enzyme was eluted from the column as a single and symmetrical peak (fig 2 ). Results of the purification are summarized in table II. Using this protocol the proline iminopeptidase was purified $\approx 80$-fold with a yield of $7 \%$ from the crude extract.
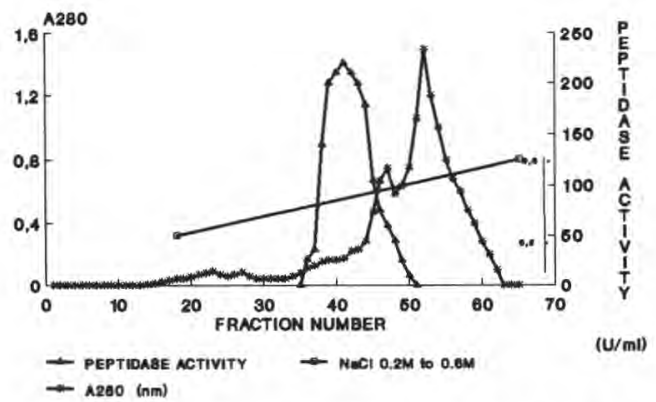

Fig 1. First ion exchange chromatography. Purification of aminopeptidase from intracellular fraction of $P$ shermanii 13673. Elution pattern of the peptidase from a Fractogel TSK DEAE 650 column. The peptidase activity $\lambda\left(A_{410}\right)$ was assayed with Pro $p$-NA substrate.

Première chromatographie d'échange d'ions. Purification de l'aminopeptidase à partir de la fraction intracellulaire de $\mathrm{P}$ shermanii 13673 . Profil d'élution de la peptidase de la colonne de Fractogel TSK DEAE 650. L'activité de la peptidase $\lambda\left(A_{410}\right)$ a été testée avec le substrat Pro p-NA.

\section{Peptidase characterization}

\section{Molecular weight determination}

The enzyme preparation showed a single band after SDS-PAGE. The molecular weight of the enzyme was estimated at 61000 even in the presence of 2mercaptoethanol (data not shown) (fig 3 ). The peptidase was also found to have a molecular weight of 61000 by gel filtration.

\section{Effect of $\mathrm{pH}$ and temperature on enzyme activity}

The optimal $\mathrm{pH}$ for Pro $\mathrm{p}-\mathrm{NA}$ hydrolysing activity appeared to be $\mathrm{pH} 8.0$ (fig $4 \mathrm{~A}$ ). At $\mathrm{pH} 5.0$ and 9.0 , hydrolysing activity was also detected. The optimal temperature for

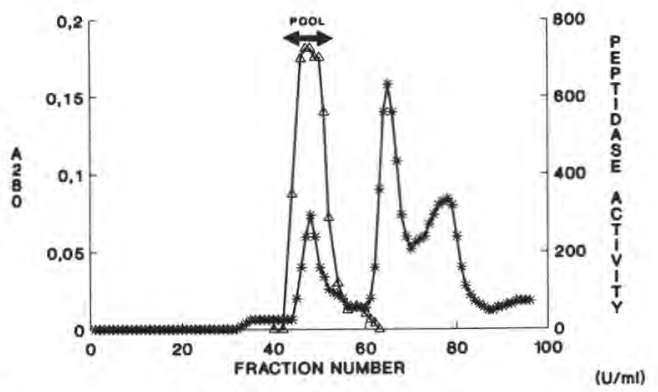

Fig 2. Gel filtration on Sephacryl S-100 HR. Purification of peptidase from $P$ shermanii 13673 after the second ion exchange chromatography on a Sephacryl S-100 HR column. The peptidase activity $\lambda\left(A_{410}\right)$ was assayed with Pro $p$ NA substrate.

Gel filtration sur Sephacryl S-100 HR. Purification de la peptidase de $\mathrm{P}$ shermanii 13673 après la seconde chromatographie d'échange d'ions sur colonne de Sephacryl S-100 HR. L'activité de la peptidase $\lambda\left(A_{410}\right)$ a été testée avec le substrat Prop-NA. 
Table II. Purification of the peptidase from $P$ shermanii 13673.

Purification de la peptidase de P shermanii 13673

\begin{tabular}{lcccccc}
\hline $\begin{array}{l}\text { Purification } \\
\text { step }\end{array}$ & Vol & $\begin{array}{l}\text { Total } \\
\text { protein } \\
(m g)\end{array}$ & $\begin{array}{l}\text { Total* } \\
\text { activity } \\
(\mathrm{U})\end{array}$ & $\begin{array}{l}\text { Specific } \\
\text { activity } \\
(\mathrm{m} / \mathrm{mg})\end{array}$ & $\begin{array}{l}\text { Yield } \\
(\%)\end{array}$ & $\begin{array}{l}\text { Purification } \\
(\text { fold })\end{array}$ \\
\hline $\begin{array}{l}\text { Crude cell extract } \\
\begin{array}{l}\text { 1st Fractogel } \\
\text { TSK DEAE 650 }\end{array}\end{array}$ & 100 & 3000 & 14248 & 4.75 & 100 & 1 \\
$\begin{array}{l}\text { 2nd Fractogel } \\
\text { TSK DEAE 650 }\end{array}$ & 100 & 110 & 2330 & 21.2 & 16.3 & 4.4 \\
Sephacryl S-100 HR & 10 & 40 & 2260 & 56.5 & 15.8 & 11.9 \\
\hline
\end{tabular}

" Determined with the substrate Pro p-NA; " Déterminé avec le substrat Prop-NA

Pro $p$-NA hydrolysing activity was found to be $40^{\circ} \mathrm{C}$ (fig $4 \mathrm{~B}$ ). Significant activity was detected at 35 and $45^{\circ} \mathrm{C}$; at $20^{\circ} \mathrm{C}, 50 \%$ of specific activity was detected, but at $55^{\circ} \mathrm{C}$ only $9 \%$ of the optimal activity was noted.

\section{Substrate specificity}

The purified enzyme was incubated with $p$ nitroanilide derivatives of amino acids or dipeptides, and with dipeptides and tripeptides (table III). Pro $p$-NA had the highest activity among the p-NA substrates. The purified enzyme catalyzed hydrolysis of dipeptides only if they had a proline residue in the N-terminal position: Pro-Phe, ProMet, Pro-Leu, Pro-lle, Pro-Gly. Carbobenzoxy peptides were not hydrolyzed by the enzyme. The purified peptidase had the same high specificity for Pro $p-N A$ as the intracellular fraction. The peptidase had no action on $\beta$-casomorphin fragments $1-3$, $1-4$ and $1-5$ (table IV). But the peptidase was able to hydrolyze specifically the $\beta$ casomorphin des-Tyr-fragment 7: Pro-PhePro-Gly-Pro-lle. After $3 \mathrm{~h}$ of incubation at $40^{\circ} \mathrm{C}$ the peptidase hydrolysed $\approx 50 \%$ of the substrate. This specific hydrolysis was continuous with time (data not shown). For identification of released products we injected proline as a marker. Under our conditions; Pro was not detectable. It is likely that the peak which appeared was the Phe-Pro-Gly-Pro-lle peptide. Morever, this could be confirmed by identification of this peptide by amino acid analysis.

\section{Effect of chemical reagents and inhibitors}

Treatment of the peptidase with several agents is summarized in table $\mathrm{V}$. The rate of Pro p-NA hydrolysis in the absence of any reducing agent, metal chelator or inhibitor was taken as $100 \%$. The enzyme activity was reduced to $30 \%$ when incubated in $1.0 \mathrm{mM}$ phenylmethylsulfonyl fluoride (PMSF), a specific inhibitor for serine protease. The metal-complexing agents EDTA $(10 \mathrm{mM})$ and bestatin also decreased enzyme activity, indicating a metal ion requirement. Sulfhydryl inhibitors had some effect on the proline iminopeptidase activity, whereas dithiothreitol and 2- 


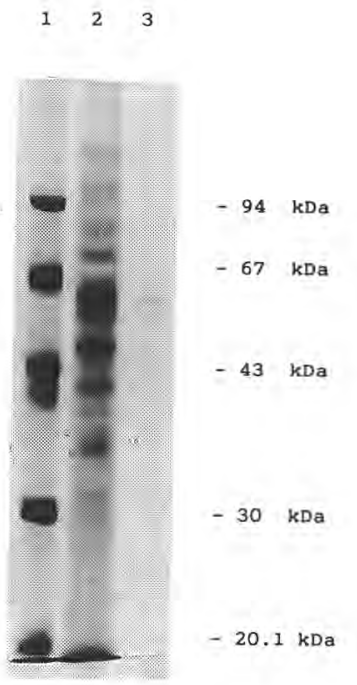

Fig 3. SDS-polyacrylamide gel electrophoresis. 1, Low molecular weight standards: from top to bottom, phosphorylase b (94 kDa), bovine serum albumin (67 kDa), ovalbumin (43 kDa), bovine carbonic anhydrase $(30 \mathrm{kDa})$, soybean trypsin inhibitor $(20.1 \mathrm{kDa}) .2$, Crude intracellular extract from $P$ shermanii 13673. 3, Purified peptidase $(1.6 \mu \mathrm{g}$ of protein) after gel filtration on Sephacryl S-100 HR.

Electrophorèse en gel de SDS-polyacrylamide. 1. Standards de faible poids moléculaire : de haut en bas, phosphorylase b (94 kDa), albumine bovine (67 kDa), ovalbumine (43 kDa), anhydrase carbonique bovine (30 kDa), inhibiteur trypsique de soja (20.1 kDa); 2, Extrait intracellulaire brut de $\mathrm{P}$ shermanii 13673; 3, Peptidase purifiée (1.6 $\mathrm{g}$ de protéine) après gel filtration sur Sephacryl S-100 HR.

mercaptoethanol had no effect on enzyme activity.

Several divalent metal ions were tested (fig 5). Addition of $0.1 \mathrm{mM}$ Co acetate, $\mathrm{Cu}$ sulfate, $\mathrm{Fe}$ sulfate inhibited the enzyme activity by 20,53 and $77 \%$ respectively. A complete inhibition was observed with 0.1 $\mathrm{mM} \mathrm{Zn}$. Addition of $0.1 \mathrm{mM} \mathrm{Ca}$ and $\mathrm{Mg}$ chloride had no inhibitory effect.

\section{Amino acid composition}

The amino acid composition is shown in table VI. The peptidase contained moderate quantities of hydrophobic amino acids, consistent with the intracellular origin of the protein.

\section{DISCUSSION}

In the present study a proline iminopeptidase was purified from the intracellular fraction of $P$ shermanii 13673 in several steps. Purification, as estimated from the specific activity, was approximately 80 -fold with a yield of $7 \%$; but protein purification of $\approx 1000$-fold was achieved. During the different steps of purification, inactivation apparently occurred in spite of the presence of stabilizers. The proline iminopeptidase of $P$ shermanii 13673 has a molecular weight of 61000 as estimated by SDSPAGE and gel filtration. In comparison the aminopeptidase from $S$ thermophilus has a molecular weight of 62000 , and its dipeptidase 50000 (Rabier and Desmazeaud, 1973), whereas the aminopeptidase from $L$ lactis has a molecular weight of 78000 to 81000 (Eggimann and Bachmann, 1980). The prolyl-dipeptidyl aminopeptidase from $L$ helveticus has a molecular weight of 72000 (Khalid and Marth, 1990) and the $X$-prolyl-dipeptidyl-aminopeptidase from $L$ lactis and from $S$ thermophilus has a molecular weight of $\approx 165000 \mathrm{Da}$ (Meyer and Jordi, 1987). Incubation of the enzyme with dithiothreitol or 2-mercaptoethanol had no effect on enzyme activity, suggesting that an intact disulphide group was not essential for the mechanism of action of this enzyme. The enzyme was more markedly inhibited by phenylmethylsulphonyl fluoride $(1 \mathrm{mM})$. These results suggest that the enzyme is a serine protease. Bacterial dipeptidyl aminopeptidases from $L$ lactis, and $S$ 
Table III. Relative activity* of the peptidase with different substrates.

Activité relative de la peptidase avec différents susbstrats.

\section{Substrate}

Relative activity

(\%)

Substrate

100
0
0
0
0
0
0
0
0
0
0

Relative activity

(\%)

$\begin{array}{lr}\text { Pro-Phe } & 100 \\ \text { Pro-Met } & 75 \\ \text { Pro-Leu } & 50 \\ \text { Pro-Ile } & 40 \\ \text { Pro-Gly } & 16 \\ \text { Phe-Pro } & 0 \\ \text { Met-Pro } & 0 \\ \text { Val-Pro } & 0 \\ \text { Lys-Phe } & 0 \\ \text { Met-Ala } & 0 \\ \text { Leu-Ala } & 0 \\ \text { Met-Asp } & 0 \\ \text { Phe-Phe } & 0 \\ \text { Leu-Leu } & 0 \\ \text { Ala-Phe } & 0 \\ \text { Tyr-Ala } & 0 \\ \text { Leu-Phe } & 0 \\ \text { Ala-Leu } & 0 \\ \text { Leu-Tyr } & 0 \\ \text { Leu-Pro } & 0 \\ \text { His-Phe } & 0 \\ \text { Met-Leu } & 0 \\ \text { Phe-Tyr } & 0 \\ \text { Ala-Pro } & 0 \\ \text { Leu-Gly } & 0 \\ \text { Gly-Phe } & 0 \\ \text { Leu-Gly-Gly } & 0 \\ \text { Ala-Leu-Gly } & 0 \\ \text { Leu-Leu-Leu } & 0 \\ \text { Phe-Gly-Gly } & 0 \\ \text { Gly-Phe-Phe } & 0 \\ \text { N CBZ Pro-Leu } & 0 \\ \text { N CBZ Phe-Leu } & 0 \\ & \end{array}$

* Expressed as percentage of maximal activity measured with p-NA substituted amino acids, dipeptides or tripeptides; " Exprimée en pourcentage de l'activité maximale mesurée avec les acides aminés substitués ( $P$-NA), dipeptides ou tripeptides.

thermophilus were also found to be serine proteases (Meyer and Jordi, 1987). The enzyme was also inhibited by EDTA, thus indicating a requirement for metal ion. The same inhibition pattern was observed with the enzymes from $S$ thermophilus (Meyer and Jordi, 1987). The enzyme was completely inactivated by $0.1 \mathrm{mM} \mathrm{Zn}$ and less inactivated by $\mathrm{Co}, \mathrm{Cu}$ and $\mathrm{Fe}$. Divalent ions $\mathrm{Ca}$ and $\mathrm{Mg}$ had no effect on the en- 
Table IV. Substrate specificity of the peptidase with B-casomorphin fragments. Hydrolysis of B-casomorphin fragments was followed by HPLC. After incubation for $3 \mathrm{~h}$ at $40^{\circ} \mathrm{C}$, the reactional mixture was injected onto a Vydac C $185 \mu$ column and elution was performed with water/acetonitrile gradient.

Specificité de substrats de la peptidase avec les fragments de B-casomorphine. L'hydrolyse des fragments de B-casomorphine a été suivie par HPLC. A près une incubation de $3 \mathrm{~h}$ à $40^{\circ} \mathrm{C}$, le mélange réactionnel a été injecté sur une colonne Vydac $\mathrm{C} 185 \mu$ et l'élution faite par un gradient eau/ acétonitrile.

B-casomorphin 1-3-fragment

(Tyr-Pro-Phe)

\section{Morphiceptin or}

B-casomorphin 1-4 fragment

(Tyr-Pro-Phe-Pro-NH2)

B-casomorphin 1-5 fragment

(Tyr-Pro-Phe-Pro-Gly)
B-casomorphin des-Tyr-fragment 7

(Pro-Phe-Pro-Gly-Pro-Ile) zyme. The enzyme was most active at $\mathrm{pH}$ 8.0. This result can be compared to the broad $\mathrm{pH}$ optima of enzymes of $S$ thermophilus: $\mathrm{pH}$ 6.0-8.5 (Rabier and Desmazeaud, 1973).

The optimum temperature was $40^{\circ} \mathrm{C}$. The stability of the proline iminopeptidase was high, $50 \%$ of the initial activity still re-

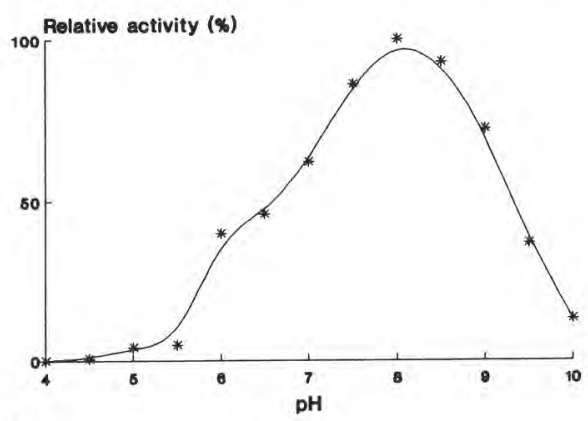

FiQ.4A maining at $50^{\circ} \mathrm{C}$. The considerable activity of this peptidase at $10^{\circ} \mathrm{C}(38 \%$ of relative activity), as well as its good stability at $\mathrm{pH}$ 6.0 indicate the potential role that it may have during cheese ripening in the liberation of amino acids. The quantity of intracellular enzyme is quite large. However, curd conditions are unlike the experimental

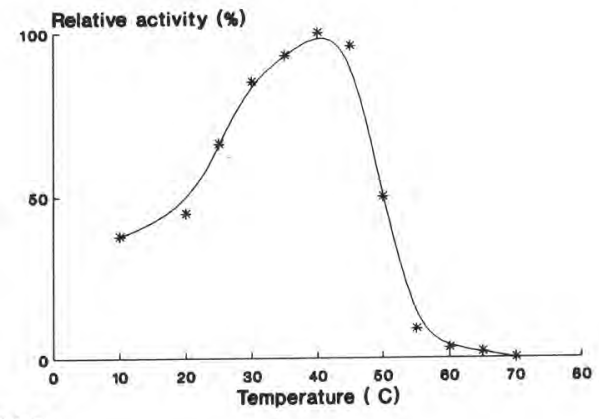

FIQ.4B

Fig 4. Effect of $\mathrm{pH}(\mathrm{A})$ and temperature $(B)$ on peptidase activity. The peptidase activity $\left(A_{410}\right)$ was assayed with Pro $p$-NA substrate. Role du $\mathrm{pH}(\mathrm{A})$ et de la température (B) sur l'activité de la peptidase. L'activité de la peptidase a été testée avec le substrat Pro $\mathrm{p}-\mathrm{NA}$. 
Table V. Inhibition of peptidase activity. Inhibition de l'activité de la peptidase.

$\begin{array}{ll}\text { Inhibitor } & \begin{array}{l}\text { Concentration } \\ (\mathrm{mM})\end{array}\end{array}$

\begin{tabular}{lrr}
\hline & 0.1 & 100 \\
Dithiothreitol & 1 & 100 \\
L-Cysteine & 0.1 & 100 \\
2-Mercaptoethanol & 1 & 90 \\
& 0.1 & 100 \\
N-Ethylmaleimide & 1 & 100 \\
& 0.1 & 100 \\
lodoacetic acid & 1 & 96 \\
& 0.1 & 100 \\
lodoacetamide & 1 & 90 \\
& 0.1 & 100 \\
p-Chloromercuric benzoic acid & 1 & 96 \\
& 0.1 & 100 \\
EDTA & 1 & 100 \\
& 1 & 97 \\
1.10-Phenanthroline & 10 & 62 \\
& 0.1 & 100 \\
Bestatin & 1 & 100 \\
& 0.1 & 90 \\
Phosphoramidon & 1 & 75 \\
Phenylmethylsulfonyl fluoride & 0.1 & 100 \\
& 0.1 & 75 \\
Pepstatin A & 1 & 30 \\
Sodium citrate & 0.1 & 100 \\
& 1 & 100 \\
& 0.1 & 100 \\
& 1 & 100 \\
\hline
\end{tabular}

conditions: uncontrolled $\mathrm{pH}$ values, no lysis during the exponential phase.

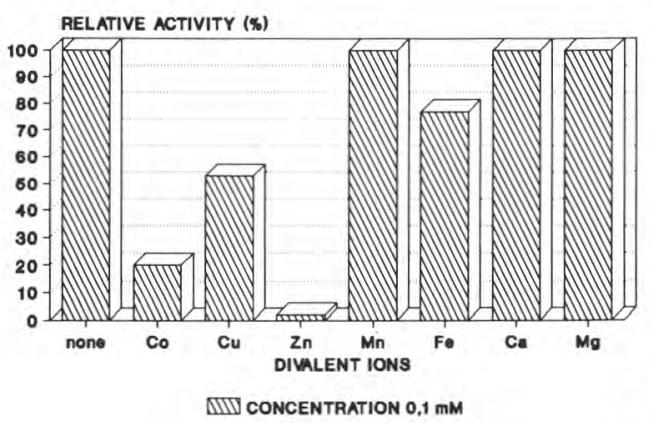

After production of Swiss cheese, the $\mathrm{pH}$ is approximately 5.2 and rises to 5.65.8 during maturation. Also, during the ripening process the cheese is stored at different temperatures between $10-24^{\circ} \mathrm{C}$. During maturation the conditions are not optimal for peptidase activity. But during all

Fig 5. Effect of divalent ions on peptidase activity. The relative peptidase activity was measured by the release of $p$-nitroanilide which was followed spectrophotometrically.

Rôle des ions divalents sur l'activité de la peptidase. L'activité relative de la peptidase a été mesurée par la libération de p-nitroanilide suivie au spectrophotomètre. 
Table VI. Amino acid composition of the proline iminopeptidase of $P$ shermanii 13673. Composition en acides aminés de la proline iminopeptidase de P shermanii 13673.

\begin{tabular}{lcc}
\hline Amino acid & $\begin{array}{c}\text { Quantity } \\
(\mathrm{nmol})\end{array}$ & $\begin{array}{c}\text { Molar ratio } \\
(\%)\end{array}$ \\
\hline Aspartic acid/asparagine & 11.1 & 9.3 \\
Threonine & 6.5 & 5.4 \\
Serine & 7.5 & 6.3 \\
Glutamic acid/glutamine & 7.3 & 6.2 \\
Proline & 2.7 & 2.3 \\
Glycine & 8.8 & 7.4 \\
Alanine & 13.7 & 11.5 \\
Cysteine & 2.5 & 2.1 \\
Valine & 9.1 & 7.6 \\
Methionine & 0.5 & 0.4 \\
Isoleucine & 4.7 & 3.9 \\
Leucine & 7 & 5.9 \\
Tyrosine & 0.3 & 0.3 \\
Phenylalanine & 5 & 4.2 \\
Histidine & 2.8 & 0.4 \\
Lysine & 3.6 & 3.6 \\
Arginine & 5.4 & 4.5 \\
Tryptophan & nd & \\
\hline
\end{tabular}

the ripening process of $4-6$ weeks, the temperature and $\mathrm{pH}$ values are favourable for peptidase activity. The purified enzyme catalyzed hydrolysis of dipeptide and peptide derivatives containing proline residues in the ultimate position. Pro-X peptides were specifically hydrolyzed. The X-Pro peptides were resistent to enzymatic hydrolysis. The enzyme was identified as a proline iminopeptidase also with a prolinase activity, according to the possible sequences of enzyme activities proposed by Booth et al (1990). Several peptidases have been isolated and characterized in $S$ cremoris (Geis et al, 1985; Exterkate and de Veer, 1987; Van Boven et al, 1988), and $L$ lactis (Tan and Konings, 1990). None is capable of releasing $N$ terminal prolyl residues. Beta-casomorphin des-Tyr was a good substrate for the proline iminopeptidase of $P$ shermanii 13673.
The X-prolyl dipeptidyl peptidase purified from $L$ lactis (Zevaco et al, 1990) hydrolyzed the $\beta$-casomorphin producing 4 different peptides.

In Swiss type cheese proteinases from lactic acid bacteria provide peptides from caseins. These peptides will be further cleaved by peptidases. Peptide hydrolases from starters may include aminopeptidases with broad substrate specificities, dipeptidases, and finally leucine aminopeptidase or proline iminopeptidase in order to release essential amino acids for cell nutrition. Degradation of casein by the action of chymosin or other enzymes can result in formation and accumulation of bittertasting peptides in cheese (Vegarud and Langsrud, 1989).

Bitter-tasting peptides consistently have a high proportion of hydrophobic amino acid residues. Bitterness will not develop if 
specific peptidolytic enzymes with debittering properties are present (Ardo et al, 1989). Proline-containing peptides exhibited bitterness (Ishibashi et al, 1988). This flavor defect may occur during accelerated ripening of cheese. Consequently, sufficient intracellular peptidases from starter cells is a critical point in the release of amino acids and debittering of dairy products. The propionibacteria also produce intracellular peptidases which are released in the cheese by autolysis (Langsrud et al, 1978b). Earlier observations by Langsrud et al (1977) suggested that prolinereleasing peptidases predominate in $P$ shermanii. Proline has a sweet taste and its presence in particularly high concentrations in Emmental cheese led Langsrud and Reinbold (1973) to suggest that this constituted the basis of this aspect of Swiss cheese flavor. In this paper we have described the presence of a proline iminopeptidase which enables $P$ shermanii 13673 to release free proline from intermediary products of protein breakdown as observed by Langsrud et al (1978a).

Heat and freeze-shocking of propionibacteria can be tested to accelerate ripening of cheese, according to Frey et al (1986) and Bartels et al (1987a, b), cheese manufacturers being interested in producing mature-flavoured products in a short period of time. More research is needed to obtain strains with lytic properties as well as a high content of stable intracellular enzymes.

\section{REFERENCES}

Andrews BA, Asenjo JA (1987) Enzymatic lysis and disruption of microbial cells. Tibtech 5, 273-277

Ardo $\mathrm{Y}$, Larsson PO, Lindmark Mansson $\mathrm{H}, \mathrm{He}$ denberg $A$ (1989) Studies of peptidolysis during early maturation and its influence on low- fat cheese quality. Milchwissenschaft 44, 485-490

Bartels HJ, Johnson ME, Olson NF (1987a) ACcelerated ripening of Gouda cheese. I. Effect of heat-shocked thermophilic lactobacilli and streptococci on proteolysis and flavor development. Milchwissenschaft 42, 83-88

Bartels HJ, Johnson ME, Olson NF (1987b) Accelerated ripening of Gouda cheese. II. Effect of freeze-shocked Lactobacillus helveticus on proteolysis and flavor development. Milchwissenschaft 42, 139-144

Booth M, Donnelly WJ, Ni Fhaolain I, Jennings PV, O'Cuinn G (1990) Proline-specific peptidases of Streptococcus cremoris AM2. J Dairy Res 57, 79-88

Bradford MM (1976) A rapid and sensitive method for the quantitation of microgram quantities of protein utilizing the principle of proteindye binding. Anal Biochem 72, 248-254

Britz TJ, Steyn PL (1980) Comparative studies on proprionic acid bacteria. Phytophylactica $12,89-103$

Casey MG, Meyer J (1985) Presence of Xprolyl-dipeptidyl-peptidase in lactic acid bacteria. J Dairy Sci68, 3212-3215

Desmazeaud MJ, Juge M (1976) Caractérisation de l'activité protéolytique et fractionnement des dipeptidases et des aminopeptidases de Streptococcus thermophilus. Lait 56, 241-260

Eggimann B, Bachmann M (1980) Purification and partial characterization of an aminopeptidase from Lactobacillus lactis. Appl Environ Microbiol 40, 876-882

El Soda M, Desmazeaud MJ (1982) Les peptide-hydrolases des lactobacilles du groupe Thermobacterium. I. Mise en évidence de ces activités chez Lactobacillus helveticus, $L$ acidophilus, $L$ lactis et $L$ bulgaricus. Can $J$ Microbiol 28, 1181-1188

Exterkate FA, de Veer GJCM (1987) Purification and some properties of a membrane-bound aminopeptidase A from Streptococcus cremoris. Syst Appl Microbiol 9, 183-191

Ezzat N, El Soda M, Desmazeaud MJ, Ismail A (1982) Peptide hydrolases from the Thermobacterium group of lactobacilli. II. Physiological factors and enzyme production. Milchwissenschaft $37,666-668$ 
Fox PF (1989) Proteolysis during cheese manufacture and ripening. $J$ Dairy Sci $72,1379-$ 1400

Frey JP, Marth EH, Johnson ME, Olson NF (1986) Heat-and freeze-shocking cause changes in peptidase and protease activity of Lactobacillus helveticus. Milchwissenschaft 41, 681-685

Geis A, Bockelman W, Teuber M (1985) Simultaneous extraction and purification of a cell wall-associated peptidase and $\beta$-casein specific protease from Streptococcus cremoris AC1. Appl Microbiol Biotechnol 23, 79-84

Hettinga DH, Vedamuthu ER, Reinbold GW (1968) Pouch method for isolating and enumerating propionibacteria. J Dairy Sci 51 , 1707-1709

Hickey MW, Hillier AJ, Jago GR (1983) Peptidase activities in lactobacilli. Aust $J$ Dairy Technol 38, 118-123

Ishibashi $\mathrm{N}$, Kubo $\mathrm{T}$, Chino M, Fukui $\mathrm{H}$, Shinoda I, Kikuchi E, Okai H, Fukui S (1988) Taste of proline-containing peptides. Agric Biol Chem 52, 95-98

Kamaly KM, Marth EH (1989) Enzyme activities of lactic streptococci and their role in maturation of cheese: a review. J Dairy Sci 72, 1945-1966

Khalid NM, Marth EH (1990) Purification and partial characterization of a prolyl-dipeptidyl aminopeptidase from Lactobacillus helveticus CNRZ 32. Appl Environ Microbiol 56, 381-388

Kondo JK, McKay LL (1982) Mutanolysin for improved lysis and rapid protoplast formation in dairy streptococci. J Dairy Sci 65, 1428-1431

Laemmli UK (1970) Cleavage of structural proteins during the assembly of the head of bacteriophage T4. Nature (Lond) 227, 680-685

Langsrud T (1974) Proline production by propionibacteria. Thesis, lowa State University Library, Ames, lowa

Langsrud T, Reinbold CW (1973) Flavour development and microbiology of Swiss cheese a review. J Milk Food Technol 36, 487-490

Langsrud T, Reinbold GW, Hammond EG (1977) Proline production by Propionibacterium shermanii P59. J Dairy Sci 60, 16-23
Langsrud T, Reinbold GW, Hammond EG (1978a) Free proline production by strains of propionibacteria. J Dairy Sci61, 303-308

Langsrud T, Reinbold GW, Hammond EG (1978b) Autolysis of propionibacteria. XX Int Dairy Congr E, 595-596

Meyer J, Jordi R (1987) Purification and characterization of X-prolyl-dipeptidylaminopeptidase from Lactobacillus lactis and from Streptococcus thermophilus. J Dairy Sci 70, 738-745

More WEC, Holdeman LV (1974) Genus I. Propionibacterium. In: Bergey's Manual of Determinative Bacteriology (Buchanan RE, Gibbons NE, eds) Williams and Wilkins Co,. Baltimore, 633-647

Neviani E, Boquien CY, Monnet V, Phan Thanh L, Grippon JC (1989) Purification and characterization of an aminopeptidase from Lactococcus lactis subsp cremoris AM2. Appl Environ Microbiol 55, 2308-2314

Perez Chaia A, Pesce de Ruiz Holgado A, Olivier G (1990) Peptide hydrolases of propionibacteria: effect of $\mathrm{pH}$ and temperature. $J$ Food Prot 53, 237-240

Rabier D, Desmazeaud MJ (1973) Inventaire des différentes activités intracellulaires de Streptococcus thermophilus. Purification et propriétés d'une dipeptide-hydrolase et d'une aminopeptidase. Biochimie 55, 389-404

Sahistrom S, Espinosa C, Langsrud T, Sorhaug T (1989) Cell wall, membrane and intracellular peptidase activities of Propionibacterium shermanii. J Dairy Sci 72, 342-350

Tan PST, Konings WN (1990) Purification and characterization of an aminopeptidase from Lactococcus lactis subsp cremoris Wg2. Appl Environ Microbiol 56, 526-532

Van Boven A, Tan PST, Konings WN (1988) Purification and characterization of a dipeptidase from Streptococcus cremoris Wg2. Appl Environ Microbiol 54, 43-49

Vegarud GE, Langsrud T (1989) The level of bitterness and solubility of hydrolysates produced by controlled proteolysis of caseins. J Dairy Res 56, 375-379

Zevaco C, Monnet V, Gripon JC (1990) Intracellular X-prolyl dipeptidyl peptidase from Lactococcus lactis subsp lactis: purification and properties. J Appl Bacteriol 68, 357-366 